\title{
Liquid Chromatography-Tandem Mass Spectrometry Analysis of the DNA Adducts of Aristolochic Acids
}

\author{
Wan Chan, Yufang Zheng, and Zongwei Cai \\ Department of Chemistry, Hong Kong Baptist University, Kowloon Tong, Kowloon, Hong Kong SAR, China
}

\begin{abstract}
Electrophilic attack of aristolactam-nitrenium ion by the $\mathrm{C} 7$ position to the exocyclic amino group in the DNA bases led to the formation of the major adducts. In this study, liquid chromatography coupled with electrospray ionization tandem mass spectrometry was applied to the study of DNA adducts of aristolochic acid (AA). When DNA (bases and CT-DNA) was incubated with AA, dG-AAI, dG-AAII, dA-AAI, dA-AAII, dC-AAI, and dC-AAII were detected and characterized. The $\mathrm{dC}$ adducts of $\mathrm{AA}$ were identified for the first time. The soft ionization technology allowed detection of the intact DNA adducts. High-resolution MS and MS-MS capabilities of a quadrupole time-of-flight mass spectrometer were shown to be efficient for DNA adducts analysis. DNA-AA adducts showed characteristic fragmentation patterns in MS-MS analysis. The dissociative loss of 116 Da from the DNA-AA adducts, which resulted from internal hydrogen transfer and cleavage at the $\mathrm{C}-\mathrm{N}$ glycosidic bond, provided a characteristic fragment for the structural elucidation. (J Am Soc Mass Spectrom 2007, 18, 642-650) (C 2007 American Society for Mass Spectrometry
\end{abstract}

A ristolochic acid II (AAII), 6-nitrophenanthro[3,4day]-1,3-dioxolo-5-carboxylic acid, and its 8-methoxy derivative, aristolochic acid I (AAI) are a mixture of structurally related nitrophenanthrene carboxylic acids derived from Aristolochia species [1]. Herbal medicines containing aristolochic acid (AA) have long been used to treat tumors and snake bites $[2,3]$. Recent research results, however, showed that AA is carcinogenic in rats [4-12]. During a slimming regimen in Belgium in the early 1990s, about 100 cases of renal disease were reported because of accidental replacement of Stephania tetrandra by AA-containing Aristolochia fangchi. Half of the patients required kidney replacement therapy, mostly including renal transplantation [13]. This symptom was previously described as aristolochic acid nephropathy (AAN), a unique type of rapid progress renal fibrosis associated with the prolonged intake of AA-containing Chinese herbs [13-15]. DNA-AA adducts were detected in laboratory rodents [4-12] and in patients suffering from AAN [16-18]. The DNA-AA adducts were reported as 7-(deoxyadenosine$\mathrm{N}^{6}$-yl)-aristolactam I (dA-AAI), 7-(deoxyguanosine- $\mathrm{N}^{6}$ yl)-aristolactam I (dG-AAI), 7-(deoxyadenosine- $\mathrm{N}^{6}$-yl)aristolactam II (dA-AAII), and 7-(deoxyguanosine- $N^{6}-$ yl)-aristolactam II (dG-AAII) [5].

Many toxic compounds such as polycyclic aromatic hydrocarbons [19], aromatic amine [20], heterocyclic

Published online January 5, 2007

Address reprint requests to Dr. Zongwei Cai, Department of Chemistry, Hong Kong Baptist University, Kowloon Tong, Kowloon, Hong Kong SAR, China. E-mail: zwcai@hkbu.edu.hk aromatic amines [21, 22], and acrylamides [23, 24] were found to bind covalently to DNA after metabolic activation by intrinsic enzymes. Their carcinogenicity was reported to arise from the DNA damages resulting from the formation of DNA adducts. Thus, detection of DNA adducts has been used as the biomarker for carcinogen exposure studies. DNA adduct analysis has proved to be a direct, reliable, and accurate method for the potential carcinogenicity investigation.

DNA adduct analysis by using ${ }^{32} \mathrm{P}$-postlabeling assay has been conducted extensively since the late 1970s, in which a radioactive phosphate group is introduced to the nucleotides after enzymatic DNA hydrolysis [25]. Although the ${ }^{32} \mathrm{P}$-postlabeling method is sensitive, it requires the use of a large excess of radioactive $\gamma^{32} \mathrm{P}$ labeled adenosine triphosphate-a strong $\beta$-emitterand thus poses a potential health hazard. The experiment is therefore barely performed in limited laboratories with special facilities for the control of radioactive material. The radioactive phosphate group binds to any -OH-bearing compounds in the sample, which therefore poses the risk of producing indistinguishable spots. Moreover, DNA adduct analysis by using the ${ }^{32} \mathrm{P}-$ postlabeling assay could not provide structural information for the molecule of interest. High-field NMR was previously shown to be one of the valuable tools for DNA adduct analysis [26, 27]. However, micro- to milligram samples of pure adduct are needed for structural elucidation, which is often impossible for in vivo studies.

The carcinogenicity of AA was reported to arise from the formation of DNA-AA adducts after the 
reductive activation of AA by various intrinsic enzymes [4-12, 16-18]. It was generally believed that the intermediate, that is, the aristolactam-nitrenium ion generated from nitroreduction of $\mathrm{AA}$, bound to the exocyclic amino group of the DNA bases. Electrophilic attack of the aristolactam-nitrenium ion by its $\mathrm{C} 7$ position to the exocyclic amino group in the base led to the formation of major adducts. The metabolic activation of AA to the corresponding aristolactam and DNA adducts is illustrated in Scheme $\mathbf{1}[5,11]$. DNA-AA ad-<smiles>[R]c1cccc2c1cc([N+](=O)[O-])c1c(C(=O)O)cc3c(c12)OCO3</smiles>

Aristolochic acid I (AAI): $\mathrm{R}=\mathrm{OCH}_{3}$ Aristolochic acid II (AAII): $\mathrm{R}=\mathrm{H}$<smiles>[R]c1cccc2c1cc1c3c(cc4c(c32)OCO4)C(=O)N1O</smiles>

$N$-hydroxyaristolactam

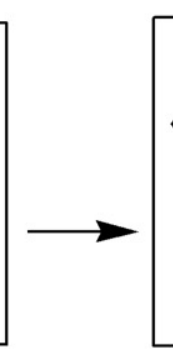

Aristolactam nitrenium ion<smiles>[R]c1cccc2c1c(O)c1c3c(cc4c(c32)OCO4)C(=O)N1</smiles>

7-hydroxyaristolactam

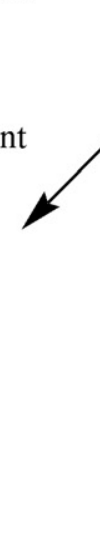

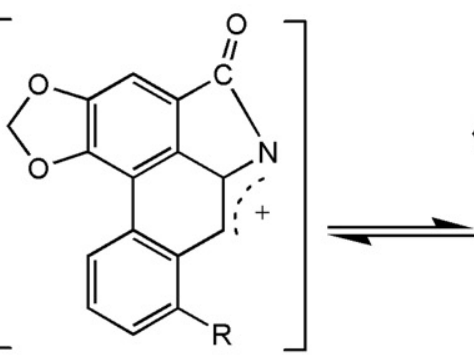

Aristolactam I: $\mathrm{R}=\mathrm{OCH}_{3}$ Aristolactam II: $\mathrm{R}=\mathrm{H}$<smiles>[R]c1cccc2c1C=C1NC(=O)C3=CC4=C(OCO3)C(=C12)OCO4</smiles><smiles>[R]c1cccc2c1c(N=c1[nH]cnc3c1ncn3[C@H]1C[C@H](O)[C@@H](CO)O1)c1c(=O)[nH]c3c4cc(c1c32)OCO4</smiles><smiles>[R]c1cccc2c1c(N=c1ccn([C@H]3C[C@H](O)[C@H](CO)O3)c(=O)[nH]1)c1c(=O)[nH]c3c4cc(c1c32)OCO4</smiles><smiles>[R]c1cccc2c1c(Nc1nc3c(ncn3[C@@H]3C[C@H](O)[C@H](CO)O3)c(=O)[nH]1)c1c3c(cc4c(c32)OCO4)C(=O)N1</smiles>

dG-AAI

dG-AAII

Scheme 1. Metabolic activation and DNA adduct formation of aristolochic acids $\left(\mathrm{AAI}, \mathrm{R}=\mathrm{OCH}_{3}\right.$; AAII, $\mathrm{R}=\mathrm{H}$ ). 
ducts were investigated extensively, in which the formed adducts were first separated by TLC or SPE followed by HPLC analysis with a radiation detector monitoring radioactivity of the effluents. The approach, however, provided no structural information for the formed adducts.

High-performance liquid chromatography coupled with mass spectrometry (LC-MS) offers a sensitive, rapid way for metabolite identification and structural elucidation [29]. The technique has been expanded to DNA adduct analysis since 1995 when Chaudhary et al. published the first LC-ESI-MS method for nucleoside analysis [30]. Soft ionization techniques—such as electrospray ionization (ESI) and atmospheric pressure chemical ionization (APCI), combined with tandem mass spectrometry-have provided high specificity and low detection limits ranging from femto- to picomoles of DNA adducts [20-22, 31, 32]. The separation capacity provided by reverse-phase LC reduces complicated steps of extraction and cleanup because adducts can readily be separated from normal nucleosides, nucleotides, and endogenous interferences.

To the best of our knowledge, a DNA binding study of AA by using LC-MS has not been reported and no structural information on $\mathrm{dC}$ adduct of AA is currently available. In the present study, the major reductive metabolites of AA and their DNA binding property have been investigated by using LC-ESI-MS-MS. This assay has the potential of being a complement or alternative to ${ }^{32} \mathrm{P}$-postlabeling analysis for detecting DNA damage induced by AA.

\section{Experimental}

\section{Chemicals}

Aristolochic acids (38\% AAI and 58\% AAII), dA, dG, $\mathrm{dC}$, calf thymus DNA (CT-DNA), DNase I, phosphodiesterase I, alkaline phosphatase, and renin substrate tetradecapeptide were obtained from Sigma (St. Louis, MO, USA). Aristolactam I and aristolactam II were synthesized from AAI/AAII as reported in Akasu et al. [33]..$^{\circ}$ HPLC-grade ${ }^{\circ}$ acetonitrile ${ }^{\circ}$ was $^{\circ}$ purchased $^{\circ}$ from Tedia (OH, USA). Water was produced by a Milli-Q Ultrapure water system with the water outlet operating at 18.2 M $\Omega$ (Millipore, Billerica, MA, USA).

\section{In Vitro Incubations with Zinc}

To $500 \mu \mathrm{L}$ of potassium phosphate buffer $(50 \mathrm{mM}, \mathrm{pH}$ 5.8), $10 \mathrm{mg}$ of zinc powder was added followed by the addition of $1 \mathrm{mg}$ of AA and $1 \mathrm{mg}$ of DNA ( $\mathrm{dA}, \mathrm{dG}, \mathrm{dC}$, or CT-DNA). The individual incubation was carried out for $16 \mathrm{~h}$ at $37^{\circ} \mathrm{C}$ according to the method described by

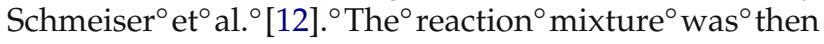
centrifuged to remove the remaining zinc dust. From the incubation of the nucleosides, the supernatant was collected and extracted with three volume of ice-cooled ethyl acetate. The extracts were collected, combined, and evaporated by a nitrogen stream at $37^{\circ} \mathrm{C}$. The dried residue was reconstituted with $50 \mu \mathrm{L}$ of methanol for the LC-MS and LC-MS-MS analyses. For the incubations of AA with CT-DNA, the collected supernatant was subjected to enzymatic DNA digestion.

\section{In Vitro Incubations with Xanthine Oxidase}

According to the procedure described by Schmeiser et ${ }^{\circ}$ al. ${ }^{\circ}[12],{ }^{\circ} \mathrm{AA}^{\circ}{ }^{\circ}$ was $^{\circ}{ }^{\circ}{ }^{\circ} o^{\circ}$ activated ${ }^{\circ}$ by ${ }^{\circ}$ incubating ${ }^{\circ}$ with $^{\circ}$ a mammalian nitro-reductase, xanthine oxidase $(\mathrm{XO})$. A mixture of AAI and AAII was added to an argonpurged potassium phosphate buffer $(50 \mathrm{mM}, \mathrm{pH} 5.8)$ containing $1.5 \mathrm{mg}$ of CT-DNA, $1 \mathrm{mM}$ hypoxanthine, and $1 \mathrm{U}$ XO. The incubation was conducted under hypoxic conditions in the dark at $37^{\circ} \mathrm{C}$ for $4 \mathrm{~h}$ before the DNA digestion.

\section{DNA Digestion and Adduct Enrichment}

Modified CT-DNA was subjected to enzymatic hydrolysis as previously ${ }^{\circ}$ described $[7]: 3.5{ }^{\circ} \mathrm{mL}^{\circ}$ of $0.01 \mathrm{M}^{\circ}$ Tris ${ }^{\circ}$ buffer, ${ }^{\circ}$ $\mathrm{mM}$ sodium chloride ( $\mathrm{pH} 7.5), 150 \mu \mathrm{L}$ DNase I (1 mg/ $\mathrm{mL}$ ), and $350 \mu \mathrm{L}$ of $0.01 \mathrm{M}$ magnesium chloride and 0.01 $\mathrm{M}$ Tris buffer ( $\mathrm{pH}$ 7.0) were added to $1 \mathrm{mg}$ of modified DNA and incubated at $37^{\circ} \mathrm{C}$ for $1 \mathrm{~h}$. The incubation was continued for another $48 \mathrm{~h}$ after addition of $4 \mathrm{~mL}$ of $0.2 \mathrm{M}$ Tris buffer ( $\mathrm{pH} \mathrm{9.0)} \mathrm{and} 0.15$ units of phosphodiesterase. Finally, $110 \mu \mathrm{L}$ of alkaline phosphatase (3.5 units $/ \mathrm{mL})$ was added and incubated for another $24 \mathrm{~h}$ before sample extraction using three volumes of ice-cold ethyl acetate. Extracts were combined, dried under a gentle stream of nitrogen, reconstituted in $50 \mu \mathrm{L}$ methanol, and centrifuged before the LC-MS analysis.

\section{LC-ESI-MS-MS Analysis}

HPLC experiments were conducted on an HP 1100 capillary system equipped with an autosapmler and a micropump (Agilent Technologies, San Francisco, CA, USA). A reverse-phase column (Waters Symmetry $\mathrm{C}_{18}$, $100 \times 2.1 \mathrm{~mm}, 3.5 \mu \mathrm{m}$ ) was used to separate DNA-AA adducts from the reductive metabolites and normal nucleosides. Injection volume was $8 \mu \mathrm{L}$. The compartment of the autosampler was set at $4{ }^{\circ} \mathrm{C}$ throughout the analysis. The mobile phase consisted of two components, with component I (A) being $0.2 \%$ acetic acid and component II (B) being acetonitrile. The solvent gradient was started from $20 \%$ B and held for $5 \mathrm{~min}$, then programmed to $80 \%$ B in $5 \mathrm{~min}$, and held for another 15 min, all at a flow rate of $200 \mu \mathrm{L} / \mathrm{min}$. The effluent of the first $5 \mathrm{~min}$ from the LC was diverted to waste to minimize the ESI source contamination.

High-resolution MS (HRMS) and MS-MS analysis were conducted on a Qq-TOF tandem mass spectrometer (API Q-STAR Pulsar i, Applied Biosystems, Foster City, CA, USA). Positive ion mode ESI-MS was used for the analysis, with the TurboIonspray parameters for AA and aristolactams optimized as follows: ionspray volt- 
age (IS) $5300 \mathrm{~V}$, declustering potential I (DPI) $20 \mathrm{~V}$, declustering potential II (DPII) $15 \mathrm{~V}$, focusing potential (FP) $40 \mathrm{~V}$. The mass range chosen ranged from $\mathrm{m} / \mathrm{z} 200$ to $m / z$ 500. The IS, DPI, DPII, and FP for DNA-AA adducts were optimized as 4500, 10, 15, and $20 \mathrm{~V}$, respectively, and full-scan mass ranged from $m / z 200$ to $m / z$ 600. The ion source gas I (GSI), gas II (GSII), curtain gas (CUR), collision gas (CAD), and the temperature of GSII were set at $30,15,30,3$, and $350{ }^{\circ} \mathrm{C}$, respectively. Mass calibration of the TOF-MS was performed by infusing $10 \mathrm{pmol} / \mu \mathrm{L}$ of renin substrate tetradecapeptide $(m / z 110.0713$ and $m / z 879.9723)$ at a flow rate of 5 $\mu \mathrm{L} / \mathrm{min}$. Product ion of the $\left[\mathrm{M}+\mathrm{NH}_{4}\right]^{+}$ion of $\mathrm{AA}$, the $[\mathrm{M}+\mathrm{H}]^{+}$ion of aristolactams and DNA-AA adducts were performed at collision energy (CE) of 30, 23, and $50 \mathrm{eV}$, respectively.

\section{Results and Discussion}

Analysis of AA and Related Reductive Metabolites

It was reported that aristolactams were the final nitroreduction ${ }^{\circ}$ product $^{\circ}$ of $^{\circ} \mathrm{AA}^{\circ}\left[28,{ }^{\circ} 29,{ }^{\circ} 34\right]$. Previous $^{\circ}$ in $^{\circ}$ vitro and in vivo studies indicated that aristolactams were the major reductive metabolites of AA after anaerobic metabolic activation. However, aristolactams were found not to be mutagenic and required exogenous metabolic ${ }^{\circ}$ activation $[28]^{\circ} .^{\circ}$ Instead, ${ }^{\circ}{ }^{\circ}{ }^{\circ} y_{c l i c}{ }^{\circ}$ aristolactamnitrenium ion with a delocalized positive charge is generally believed to be the ultimate carcinogen $\left(\text { Scheme }^{\circ} \mathbf{1}\right)^{\circ}\left[9,{ }^{\circ} 11,{ }^{\circ} 12,{ }^{\circ} 17,{ }^{\circ} 18\right] .{ }^{\circ}$ Electrophilic ${ }^{\circ}$ attack $^{\circ}$ of aristolactam-nitrenium ion by its $\mathrm{C} 7$ position to the exocyclic amino group in the purine bases led to the major ${ }^{\circ} \operatorname{adducts}^{\circ}\left[4-12,{ }^{\circ} 16^{\circ}-18\right]$.

To obtain relatively large amounts of the reductive metabolites and subsequent DNA-AA adducts for structural elucidation, in vitro incubation of AAI and AAII with zinc solution was conducted. After the 16-h incubation, it was found that majorities of AAI and AAII were reduced to their corresponding aristolactam. LC-MS analysis of the sample extracts from in vitro incubations with zinc dust showed clean extracted ion

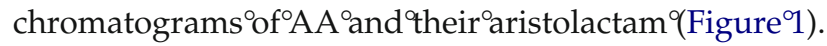
Note that ammonium salts were not used in our LC-MS protocol, but $\left[\mathrm{M}+\mathrm{NH}_{4}\right]^{+}$adduct ions were observed in
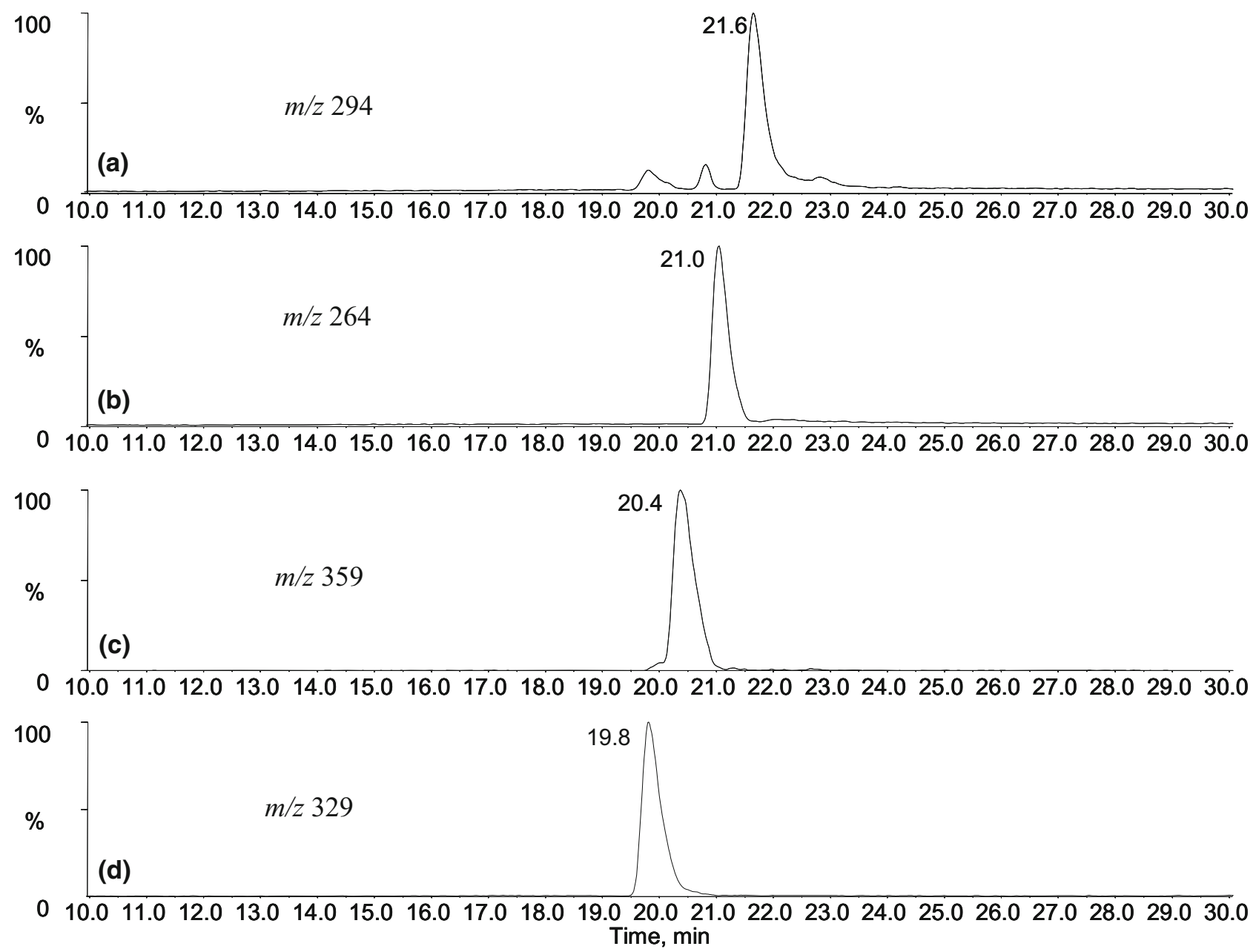

Figure 1. Extracted ion chromatogram of the $[\mathrm{M}+\mathrm{H}]^{+}$ions of $(\mathbf{a})$ aristolactam $\mathrm{I}$ and $(\mathbf{b})$ aristolactam II, as well as the $\left[\mathrm{M}+\mathrm{NH}_{4}\right]^{+}$ions of (c) AAI and (d) AAII at $\mathrm{m} / \mathrm{z} 294, \mathrm{~m} / \mathrm{z} 264, \mathrm{~m} / \mathrm{z} 359$, and $\mathrm{m} / \mathrm{z} 329$, respectively. 
the mass spectra of AAI and AAII resulting from traces of residual ammonium salts in the LC system or present in the AA standards. The $[\mathrm{M}+\mathrm{H}]^{+}$ions of aristolactam I and aristolactam II were detected at $\mathrm{m} / \mathrm{z} 294.0784$ and $\mathrm{m} / \mathrm{z}$ 264.0673, respectively, which matched the theoretical mass (294.0766 and 264.0661) with mass difference of 6.0 and $4.7 \mathrm{ppm}$, respectively.

Structural elucidation was achieved from the LCMS-MS analysis. MS-MS spectra of the $\left[\mathrm{M}+\mathrm{NH}_{4}\right]^{+}$ions of AAI $\left(m / z\right.$ 359) and AAII $(m / z ~ 329)$ and the $[\mathrm{M}+\mathrm{H}]^{+}$ ions of aristolactam I ( $\mathrm{m} / \mathrm{z} 294)$ and aristolactam II $(\mathrm{m} / \mathrm{z}$ 264) were acquired. The MS-MS spectra of AAI and AAII showed similar fragmentation patterns, with the base peak of $\left[\mathrm{M}-\mathrm{CO}_{2}+\mathrm{H}\right]^{+}$ion at $\mathrm{m} / \mathrm{z} 298$ and $\mathrm{m} / \mathrm{z} 268$, respectively. The fragmentation of aristolactam I showed $[\mathrm{M}-15]^{+}$ion at $\mathrm{m} / \mathrm{z} 279$ as the base peak, signifying the neutral loss of a methyl group. The loss of 43 Da from $[\mathrm{M}+\mathrm{H}]^{+}$ion of aristolactam I represented the loss of $-\mathrm{CONH}$ moiety from the lactam ring, which indicated the lactam formation of AA under reductive activation.

\section{Analysis of DNA-AA Adducts}

The site and sequence specificity of AA in DNA binding were studied by using zinc in potassium phosphate buffer ${ }^{\circ}\left(\mathrm{pH}^{\circ} 5.8\right)^{\circ}$ as $^{\circ}$ the ${ }^{\circ}$ activator ${ }^{\circ}[35-37]^{\circ}{ }^{\circ}$ schmeiser ${ }^{\circ} t^{\circ}{ }^{\circ}$ al. $[12]^{\circ}$ compared $^{\circ} \mathrm{DNA}{ }^{\circ}$ adducts ${ }^{\circ}$ formed ${ }^{\circ} \mathrm{by}^{\circ} \mathrm{AA}^{\circ}{ }^{\circ}{ }^{\circ}{ }^{\circ}$ various in vitro activation systems and pointed out that zinc in a slightly acidic medium was the most efficient. It was also indicated that the DNA-AA adducts produced from in vitro incubations were chromatographically identical to those from in vivo incubations. For the first time, in this study the possibility of DNA-AA adduct analysis by using LC-MS-MS was explored.

Herein, reversed-phase HPLC was applied for the separation of DNA-AA adducts from normal nucleosides and drug-related metabolites. Because it was reported that the acidicity of HPLC solvent affected the peak shape and stability of some DNA adducts in LC-MS ${ }^{\circ}$ analysis ${ }^{\circ}[22]$, the $^{\circ}$ effect ${ }^{\circ}$ of $^{\circ}$ mobile ${ }^{\circ}$ phase ${ }^{\circ}$ additive to DNA-AA adducts analysis was investigated by using $\mathrm{dA}-\mathrm{AAI}$ as the model compound. It was found that the

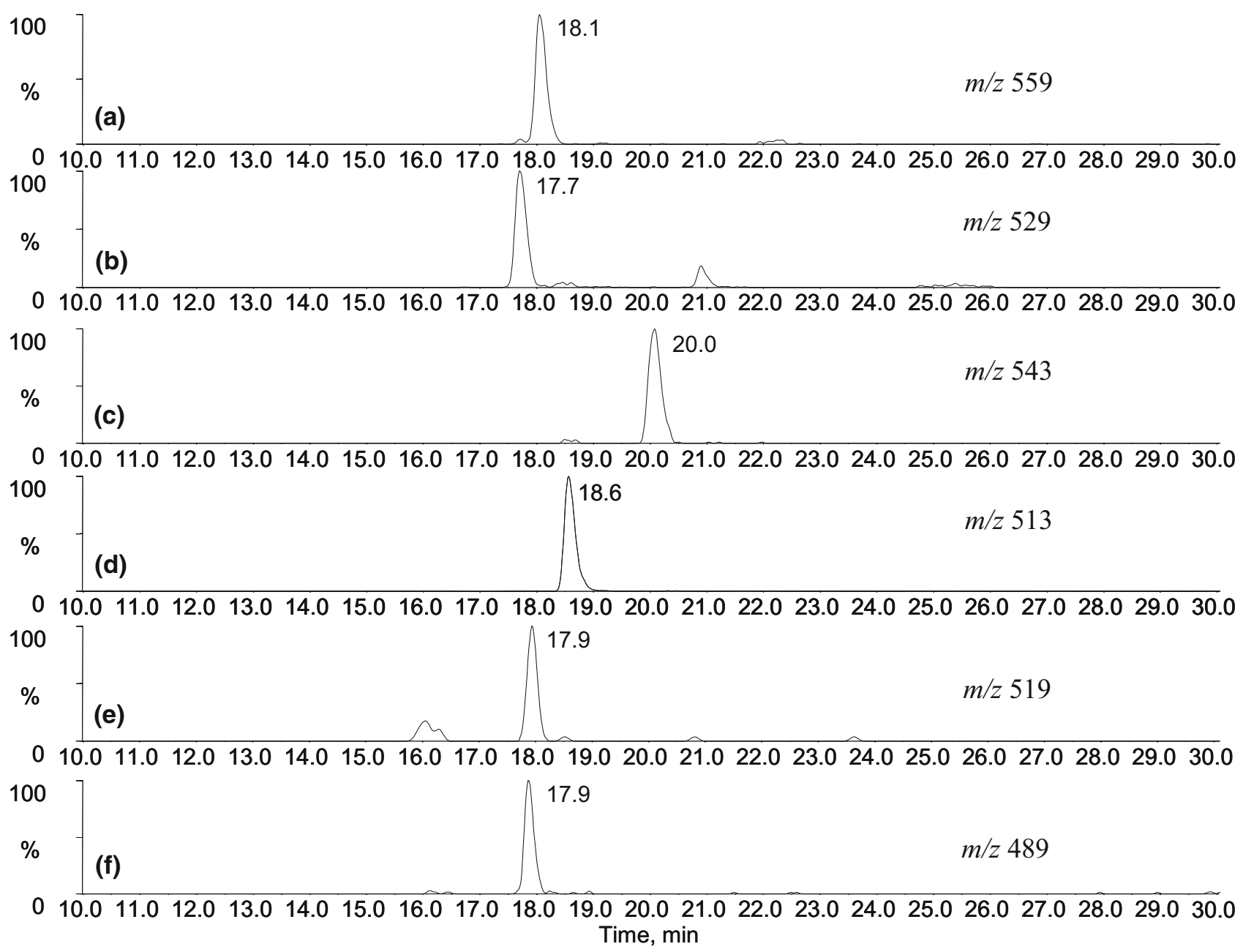

Figure 2. Extracted ion chromatogram of the $[\mathrm{M}+\mathrm{H}]^{+}$adduct ions of (a) dG-AAI, (b) dG-AAII, (c) dA-AAI, (d) dA-AAII, (e) dC-AAI, and (f) dC-AAII derived from incubating AA with zinc in potassium phosphate buffer ( $\mathrm{pH} 5.8$ ) at $\mathrm{m} / \mathrm{z} 559, \mathrm{~m} / \mathrm{z} 529, \mathrm{~m} / \mathrm{z} 543, \mathrm{~m} / \mathrm{z} 513, \mathrm{~m} / \mathrm{z} 519$, and $\mathrm{m} / \mathrm{z} 489$, respectively. 
increase of acetic acid concentration in the aqueous phase from 0.1 to $0.2 \%$ resulted in a $30 \%$ increase of peak intensity of the DNA-AA adduct. A further increase in the acid content to $0.3 \%$, however, did not show a significant change in peak intensity. It was also found that the addition of $10 \mathrm{mM}$ ammonium acetate to the aqueous phase containing $0.2 \%$ acetic acids decreased the sensitivity of the adduct by $85 \%$. An opti-
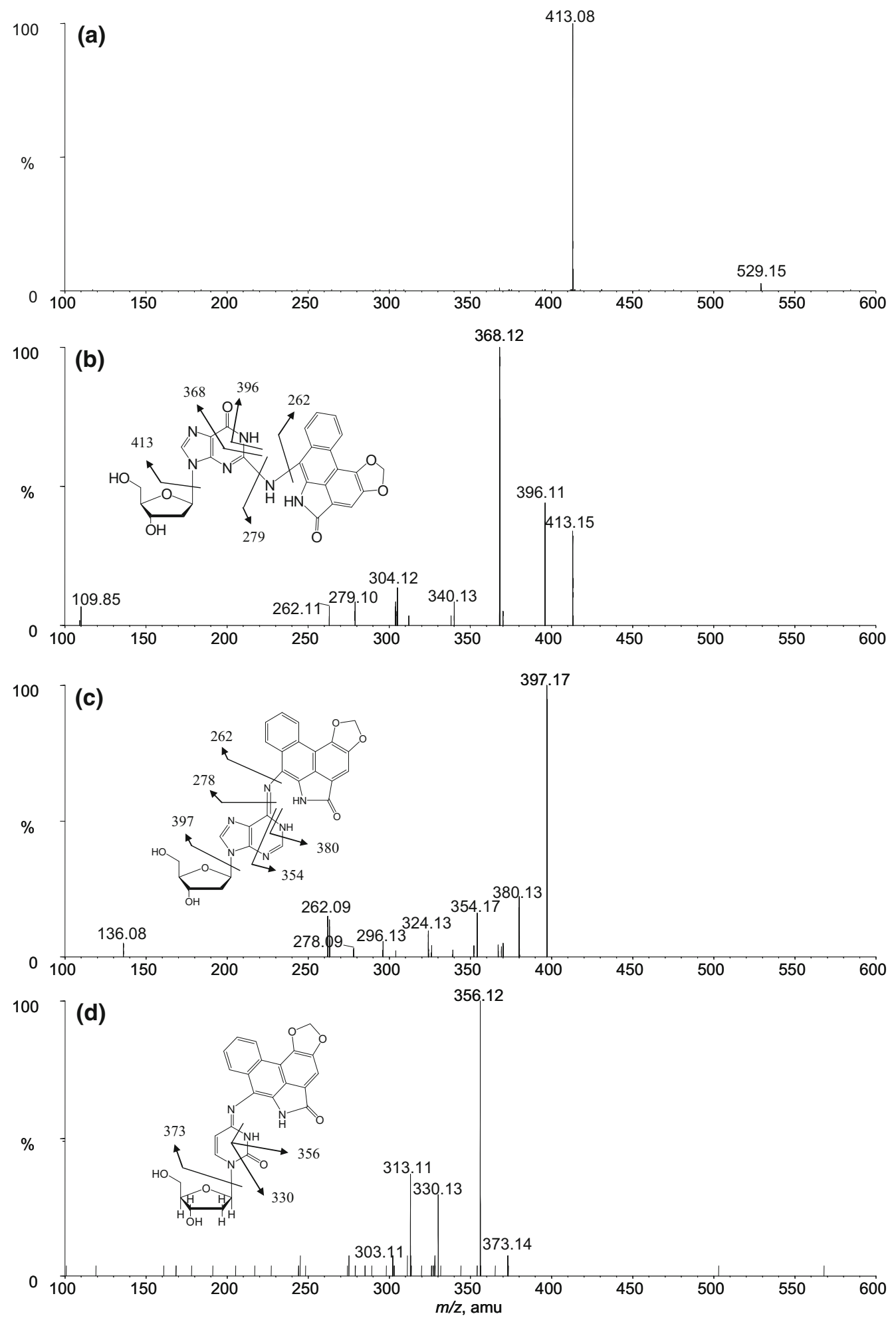

Figure 3. MS-MS spectra of the $[\mathrm{M}+\mathrm{H}]^{+}$adduct ions of (a) dG-AAII with collision energy of $20 \mathrm{eV}$, (b) dG-AAII with collision energy of $50 \mathrm{eV}$, (c) dA-AAII with collision energy of $50 \mathrm{eV}$, and (d) dC-AAII with collision energy of $50 \mathrm{eV}$. 

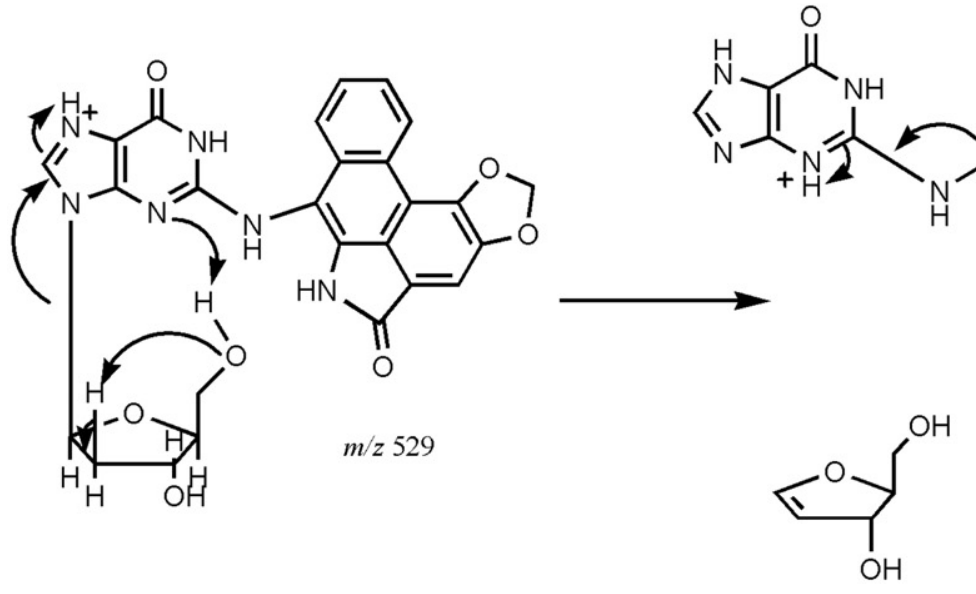

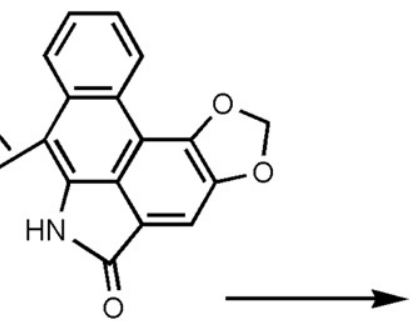

$m / z 413$

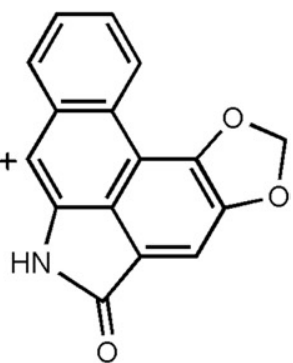

$m / z 262$

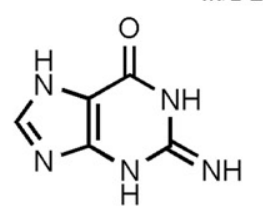

Scheme 2. Proposed fragmentation mechanism of the $[\mathrm{M}+\mathrm{H}]^{+}$ion of dG-AAII adduct.

mized mobile phase containing $0.2 \% \mathrm{CH}_{3} \mathrm{CO}_{2} \mathrm{H}$ together with a solvent gradient program was used, which allowed efficient separation of DNA-AA adducts and minimal hydrolytic degradations. The $\mathrm{dG}$ and $\mathrm{dA}$ adducts of AAI had longer retention times than that of their AAII adducts, which was similar to the retention sequence observed for AAI/AAII and their aristolactams ${ }^{\circ}\left(\right.$ Figure $\left.^{\circ} 1\right),{ }^{\circ}$ probably $^{\circ}$ because ${ }^{\circ}$ the ${ }^{\circ}$ methoxy ${ }^{\circ}$ group rendered the adducts of AAI less polar than those of AAII.

As it was reported in previous studies, DNA adducts of AA were formed by electrophilic attack at the exocyclic $^{\circ}$ amino $^{\circ}$ group $^{\circ}$ of $^{\circ}$ purine $^{\circ}\left[5,{ }^{\circ} 7 .^{\circ}{ }^{\circ} \mathrm{In}^{\circ}\right.$ this ${ }^{\circ}$ study, adducts of $\mathrm{dA}$ and $\mathrm{dG}$ were identified from the in vitro samples collected after metabolic activation with both zinc and XO. Extracted ion chromatograms of the corresponding ${ }^{\circ}[\mathrm{M}+\mathrm{H}]^{+\circ}$ ions $^{\circ}$ are $^{\circ}$ shown $^{\circ}$ in $^{\circ}$ Figure $^{\circ}$ 2, with the detection of dG-AAI, dG-AAII, dA-AAI, and dA-AAII at $\mathrm{m} / \mathrm{z}$ 559.1565, $\mathrm{m} / \mathrm{z}$ 529.1457, $\mathrm{m} / \mathrm{z}$ 543.1634, and $m / z 513.1559$, respectively. The measured accurate masses of the $[\mathrm{M}+\mathrm{H}]^{+}$ion of the DNA-AA adducts matched the theoretical mass of the corresponding elemental compositions, i.e., dG-AAI $(m / z$ 559.1577), dG-AAII $(\mathrm{m} / \mathrm{z}$ 529.1472), dA-AAI $(\mathrm{m} / \mathrm{z} 543.1628)$, and dA-AAII $(m / z$ 513.1523), with the mass difference of 2.1, $2.8,1.1$, and $7.0 \mathrm{ppm}$, respectively.

Structural elucidation was conducted by LCMS-MS analysis of the $[\mathrm{M}+\mathrm{H}]^{+}$ion of the DNA-AA adducts. The product ion spectra of the DNA-AA adducts exhibited characteristic fragmentation pattern with the loss of $116 \mathrm{Da}$, which arose from internal hydrogen transfer and fragmentation loss of a deoxyribose $^{\circ}$ moiety ${ }^{\circ}$ (Figure 3 ). ${ }^{\circ}$ For ${ }^{\circ}$ example, ${ }^{\circ}$ the ${ }^{\circ} \mathrm{MS}-\mathrm{MS}$ spectrum of dG-AAII at collision energy of $20 \mathrm{eV}$ showed the major fragment ion peak at $\mathrm{m} / \mathrm{z} 413$ resulted from the neutral loss of deoxyriobose moiety (Figure ${ }^{\circ} \mathrm{A}$ ). ${ }^{\circ}{ }^{\circ}{ }^{\circ}{ }^{\circ}$ agreement ${ }^{\circ}$ with $^{\circ}{ }^{\circ}$ previous ${ }^{\circ}$ studies, ${ }^{\circ}$ the $\mathrm{C}-\mathrm{N}$ glycosidic bond linking DNA base to the deoxyribose in modified DNA was identified as the site of $^{\circ}$ fragmentation $\left[20^{\circ} 22\right]$. The ${ }^{\circ}$ characteristic ${ }^{\circ}$ fragment ion at $m / z[\mathrm{M}-116+\mathrm{H}]^{+}$could be chosen as the quantitative ion for multiple reaction monitoring (MRM) analysis.

More structural information of DNA-AA adducts was obtained by increasing the collision energy in the MS-MS analysis. When the collision energy was increased $^{\circ}$ to $^{\circ} 50^{\circ} \mathrm{eV}^{\circ}, \mathrm{dG}^{\circ}\left(\text { Figure }^{\circ} 3 \mathrm{~B}\right)^{\circ}$ and $^{\circ} \mathrm{dA}^{\circ}$ (Figure ${ }^{\circ} 3 \mathrm{C}$ ) adducts of AAII underwent significant fragmentation to give their corresponding aristolactam ion at $m / z 262$. A specific ring cleavage product at $m / z[\mathrm{M}-116-17+\mathrm{H}]^{+}$ was also observed for dG-AAI, dG-AAII, dA-AAI, and dA-AAII adducts, which resulted from neutral loss of $\mathrm{NH}_{3}$ after fragmentation loss of the deoxyribose moiety. Fragmentation cleavages at both terminals of the $-\mathrm{N}-$ (for dG-AAII) and -N = (for dA-AAII) bond linking the aristolactam and nucleoside were also observed. This fragmentation provided hints at where the carcinogen was attached. Consistent with the reported NMR data, the targeted site for AA binding was determined as the exocyclic ${ }^{\circ}$ amino $^{\circ}$ group $^{\circ}$ in ${ }^{\circ}$ purines $^{\circ}[5]$.

The product ion spectra of dG-AAII showed the loss of $161 \mathrm{Da}$ when the collision energy was set as $50 \mathrm{eV}$, which signified the loss of deoxyribose moiety plus a cross-ring cleavage loss of -NHCO moiety from the base $^{\circ}$ (Figure $\left.{ }^{\circ} 3 \mathrm{~B}\right) .^{\circ}$ Similar $^{\circ}$ to ${ }^{\circ}$ the ${ }^{\circ}$ fragmentation ${ }^{\circ}$ mechanism ${ }^{\circ}$ proposed ${ }^{\circ}$ by $^{\circ}$ Debrauwer ${ }^{\circ}{ }^{\circ}{ }^{\circ} a .^{\circ}[38]^{\circ}$ in $^{\circ}$ the ${ }^{\circ}$ tandem mass spectrometric analysis of the deoxyguanosine adduct formed by deuterated 2-hydroxyestradiol, a fragmentation pathway for dG-AAII at high CE is proposed and illustrated in Scheme 2, showing the fragmentation at the $\mathrm{C}-\mathrm{N}$ glycosidic bonds linking the DNA base to deoxyribose $(\mathrm{m} / \mathrm{z} 413)$ and subsequently producing the aristolactam II ion $(\mathrm{m} / \mathrm{z} 262)$.

In high collision energy MS-MS analysis, dA-AAII showed [M-deoxyribose $+\mathrm{H}]^{+}$moiety and aristolactam II ions at $m / z 397$ and $m / z 262$, respectively. dA-AAII was also observed to have undergone fragmentation giving its nucleobase adenine at $\mathrm{m} / \mathrm{z} 136$ (Scheme 3 ). The product ion spectra of dA-AAII adduct also showed an additional distinguishable fragmentation at $\mathrm{m} / \mathrm{z} 354$ 

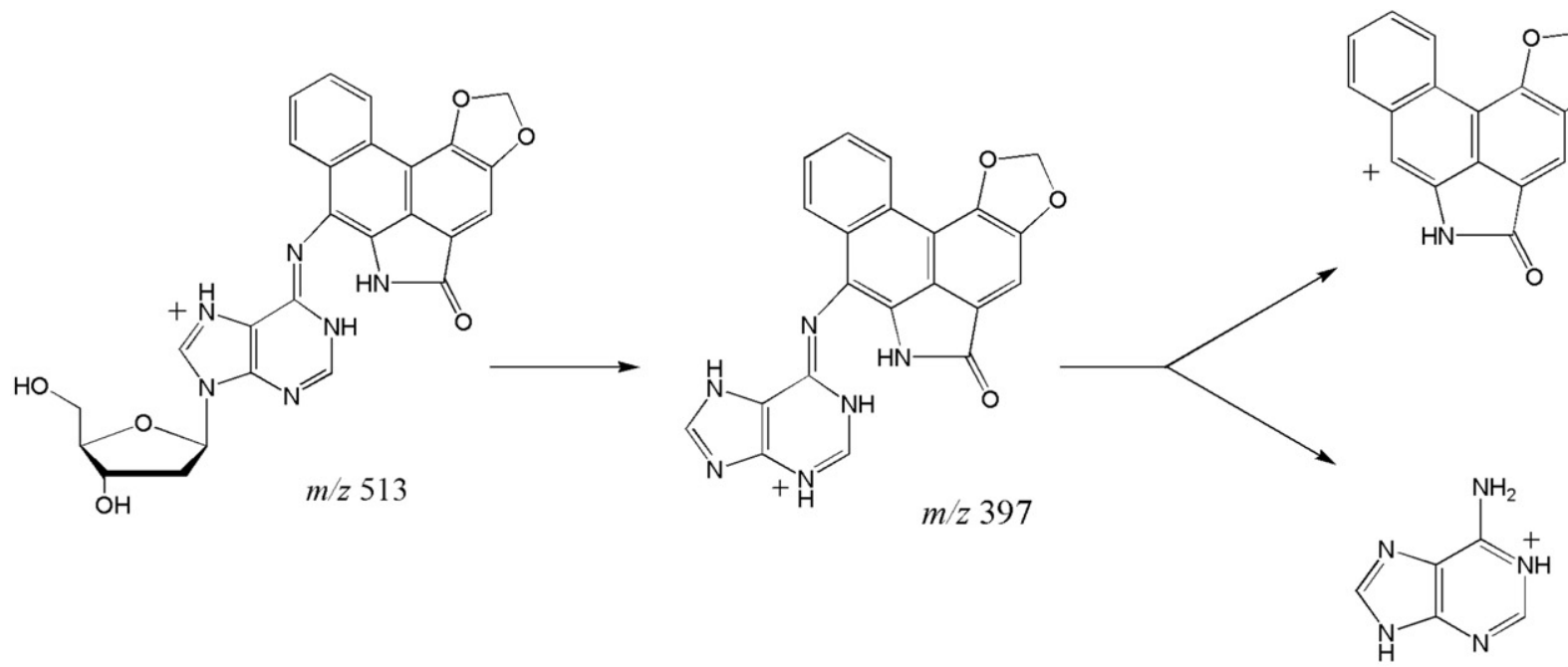

$m / z 136$

Scheme 3. MS-MS fragmentation of the $[\mathrm{M}+\mathrm{H}]^{+}$ion of dA-AAII adduct.

from the loss of $159 \mathrm{Da}$, which resulted from the cleavage of the $\mathrm{C}-\mathrm{N}$ glycosidic bond followed by ring cleavage at the base with loss of the $-\mathrm{NHCHN}$ moiety (Figure ${ }^{\circ}$ C).

AA binds to the exocyclic amino group of DNA bases $^{\circ}$ after $^{\circ}$ the ${ }^{\circ}$ metabolic ${ }^{\circ}$ activation ${ }^{\circ}\left[4^{\circ}-12,{ }^{\circ} 16^{\circ}-18\right]$. ${ }^{\circ}$ Previous DNA-AA adducts analyses focused extensively

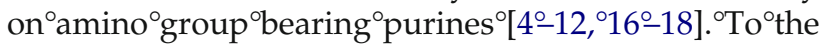
best of our knowledge, however, AA adducts of $\mathrm{dC}$ have not been reported. In this study, 7-(deoxycytidine$N^{6}$-yl)-aristolactam I (dC-AAI) and 7-(deoxycytidine$N^{6}$-yl)-aristolactam II (dC-AAII) were also detected after the in ${ }^{\circ}$ vitro ${ }^{\circ}$ activation ${ }^{\circ}{ }^{\circ} \mathrm{AA}$ (Figure 2$)$ ( $^{\circ} \mathrm{dC}$-AAII and dC-AAI were detected at $m / z 489.1453$ and $m / z$ 519.1552, respectively, with the mass difference of 8.8 and 6.9 ppm from their corresponding theoretical values. The $\mathrm{dC}$ adduct of AAI had low intensity, probably because of the presence of a methoxy group at the $\mathrm{C} 8$ position of AAI. The steric bulk and electron-donating effect might have rendered the aristolactam-nitrenium ion less reactive. The detection of dC-AAI and dC-AAII adducts indicated that LC-ESI-MS provided an additional advantage compared to the ${ }^{32} \mathrm{P}$-postlabeling analysis of DNA adducts, particularly with the capability of structural elucidation.

The $^{\circ} \mathrm{MS}^{-\mathrm{MS}^{\circ}}$ spectrum $^{\circ}$ of ${ }^{\circ} \mathrm{dC}-\mathrm{AAII}^{\circ}$ in $^{\circ}$ Figure $^{\circ} 3 \mathrm{D}^{\circ}$ is similar to that of dA-AAII and dG-AAII, showing ion peaks at $m / z 373$ attributed to the deoxyribose loss of $116 \mathrm{Da}$ and $\mathrm{m} / \mathrm{z} 356$ from the cross-ring cleavage $\mathrm{NH}_{3}$ loss. The fragment ion at $m / z 356$, resulting from the cleavage loss of $133 \mathrm{Da}$, again provided important information for structural elucidation of the deoxycytidine adducts formed. Similar to the dA-AA (dA-AAI and dA-AAII) adducts, dC-AA (dC-AAI and dC-AAII) adducts exhibited imino characteristics instead of those of secondary amine. The shift of $-\mathrm{C}=\mathrm{N}$ double-bond in $\mathrm{dC}$ from endocyclic to exocyclic allowed the formation of endocyclic $-\mathrm{NH}$ for dissociative loss of $17 \mathrm{Da}$ or the neutral loss of ammonia. The same kind of the $-\mathrm{C}=\mathrm{N}$ shift from endocyclic to exocyclic was observed in NMR analysis $^{\circ}$ of $^{\circ} \mathrm{dA}-\mathrm{AAI}^{\circ}$ and $^{\circ} \mathrm{dA}-\mathrm{AAII}{ }^{\circ}$ adducts $^{\circ}\left[5,{ }^{\circ} 7\right]$. LC-MS-MS analysis of dA-AAII also showed the fragment $^{\circ}$ ion $^{\circ}$ of $^{\circ}[\mathrm{M}-116-17+\mathrm{H}]^{+^{\circ}}$ at $^{\circ} \mathrm{m} / \mathrm{z} 380^{\circ}$ (Figure ${ }^{\circ} 3 \mathrm{C}$ ). According to the obtained MS-MS results, the structure of the deoxycytidine adduct was proposed for the first time. Confirmation of the dC-AA structure by NMR should be performed if a sufficient amount of the adduct could be collected.

\section{Conclusions}

The detection of reactive metabolites and DNA adducts of AA may be useful for the assessment on exposure to carcinogens because DNA adduct formation is an important step in the carcinogenetic pathway of AA. For the first time, dA, dG, and dC adducts of AA were detected and characterized by using LC-MS-MS. The structure of dC-AAI and dC-AAII was proposed in this study. Combining the separation efficiency of HPLC and the high sensitivity of MS, the analysis of DNA-AA adducts and aristolactam might provide an alternative to the traditional ${ }^{32} \mathrm{P}$-postlabeling assay for investigating carcinogenic AA exposure. Further investigations on the feasibility of applying the developed LC-MS method for the direct analysis of the DNA adducts as biomarkers in animal samples are currently under way.

\section{Acknowledgments}

The authors thank the Faculty Research Grant of the Hong Kong Baptist University (FRG/04-05/II-35) and the Research Grant Council, University Grants Committee of Hong Kong (HKBU2459/06M) for the financial support of this study. 


\section{References}

1. Ong, E. S.; Woo S. O.; Yong, Y. L. Pressurized Liquid Extraction of Berberine and Aristolochic Acids in Medicinal Plants. J. Chromatogr. A. 2000, 904, 57-64.

2. Kupchan, M. S.; Doskotch, R. W. Tumor Inhibitors, I. Aristolochic Acid, the Active Principle of Aristolochia indica. J. Med. Pharm. Chem. 1962, 5, 657-659.

3. Rucker, G.; Chung, B. S. Aristolochic Acids from Aristolochia manshuriensis. Plant Med. 1975, 27, 68-71.

4. Schmeiser, H. H.; Schoepe, K. B.; Wiessler, M. DNA Adduct Formation of Aristolochic Acid I and II In Vitro and In Vivo. Carcinogenesis 1988, 9, 297-303.

5. Pfau, W.; Schmeiser, H. H.; Wiessler, M. Aristolochic Acid Binds Covalently to Exocyclic Amino Group of Purine Nucleotides in DNA. Carcinogenesis 1990, 11, 313-319.

6. Pfau, W.; Schmeiser, H. H.; Wiessler, M. ${ }^{32}$ P-Postlabelling Analysis of the DNA Adducts Form by Aristolochic Acid I and II. Carcinogenesis 1990, 11, 1627-1633.

7. Pfau, W.; Schmeiser, H. H.; Wiessler, M. $N^{6}$-Adenylarylation of DNA by Aristolochic Acid II and a Synthetic Model for the Putative Proximate Carcinogen. Chem. Res. Toxicol. 1991, 4, 581-586.

8. Bieler, C. A.; Stiborova, M.; Wiessler, M.; Cosyns, J. P.; deStrihou, C. V. Schmeiser, H. H. ${ }^{32}$ P-Post-labelling Analysis of DNA Adducts Formed by Aristolochic Acid in Tissues from Patients with Chinese Herbs Nephropathy. Carcinogenesis 1997, 18, 1063-1067.

9. Stiborova, M.; Frei, E.; Wiessler, M.; Schmeiser, H. H. Human Cytochrome P450 Enzymes Involved in the Metabolic Activation of Carcinogenic Aristolochic Acids: Evidence for the Reductive Activation by CYP1A1 and CYP1A2. Chem. Res. Toxicol. 2001, 14, 1128-1137.

10. Stiborva, M.; Frei, E.; Breuer, A.; Wiessler, M.; Schmeiser, H. H. Evidence for Reductive Activation of Carcinogenic Aristolochic Acids by Prostaglandin H Synthase-P-32-postlabeling Analysis of DNA Adduct Formation. Mutat. Res. 2001, 493, 149-160.

11. Stiborova, M.; Frei, E.; Sopko, B.; Sopkova, K.; Markova, V.; Lankova, M.; Kumstyrova, T.; Wiessler, M.; Schmeiser, H. H. Human Cytosolic Enzymes Involved in the Metabolic Activation of Carcinogenic Aristolochic Acid: Evidence for Reductive Activation by Human NAD $(\mathrm{P}) \mathrm{H}$ : Quinone Oxidoreductase. Carcinogenesis 2003, 24, 1695-1703.

12. Schmeiser, H. H.; Frei, E.; Wiessler, M.; Stiborova, M. Comparison of DNA Adduct Formation by Aristolochic Acids in Various In Vitro Activation Systems by P-32-post-labelling: Evidence for Reductive Activation by Peroxidases. Carcinogenesis 1997, 18, 1055-1062.

13. Vanherweghem, J.-L.; Cuykens, J. J.; Vandenbergh, Ph.; Bouman, K. P.; Hagers, Y. Valvular Heart Disease and Chinese-Herb NephropathyReply. Lancet 1998, 351, 991-992.

14. Debelle, F. D.; Nortier, J. L.; De Prez, E. G.; Garbar, C. H.; Vienne, A. R. Salmon, I. J.; Deschodt-Lanckman, M. M.; Vanherweghem, J.-L. Aristolochic Acids Induce Chronic Renal Failure with Interstitial Fibrosis in Salt-depleted Rats. J. Am. Soc. Nephrol. 2002, 13, 431-436.

15. Vanherweghem, J.-L.; Depierreux, M.; Tielemans, C.; Abramowicz, D.; Dratwa, M.; Jadoul, M.; Richard. C.; Vandervelde, D.; Verbeelen, D. Vanhaelenfastre, R.; Vanhaelen, M. Rapidly Progressive Interstitial Renal Fibrosis in Young Women Associated with Slimming Regimen Including Chinese Herbs. Lancet 1993, 341, 387-391.

16. Bieler, C. A.; Stiborova, M.; Wiessler, M.; Cosyns, J.-P.; van Ypersele de Strihou, C.; Schmeiser, H. H. P-32-post-labelling Analysis of DNA Adducts Formed by Aristolochic Acid in Tissues from Patients with Chinese Herbs Nephropathy. Carcinogenesis 1997, 18, 1063-1067.

17. Stiborova, M.; Frei, E.; Sopko, B.; Wiessler, M.; Schmeiser, H. H. Carcinogenic Aristolochic Acids upon Activation by DT-Diaphorase Form Adducts Found in DNA of Patients with Chinese Herbs Nephropathy. Carcinogenesis 2002, 23, 617-625.

18. Arlt, V. M.; Pfohl-Loszkowicz, A.; Cosyns, J.-P.; Schmeiser, H. H. Analyses of DNA Adducts Formed by Ochratoxin A and Aristolochic Acid in Patients with Chinese Herbs Nephropathy. Mutat. Res. 2001, 494, 143-150.

19. Li, K. M.; Byun, J.; Gross, M. L.; Zamzow, D.; Jankowiak, R.; Rogan, E. G.; Cavalieri, E. L. Synthesis and Structure Determination of the Adducts Formed by Electrochemical Oxidation of Dibenzo[a,1]pyrene in the Presence of Adenine. Chem. Res. Toxicol. 1999, 12, 749-757.
20. Doerge, D. R.; Chirchwell, M. I.; Marques, M. M.; Beland, F. A. Quantitative Analysis of 4-Aminobiphenyl-C8-deoxyguanosyl DNA Adducts Produced In Vitro and In Vivo Using HPLC-ES-MS. Carcinogenesis 1999, 20, 1055-1061.

21. Soglia, J. R.; Turesky, R. J.; Paehler, A.; Vouros, P. Quantification of the Heterocyclic Aromatic Amine DNA Adduct N-(deoxyguanosin-8yl)-2-amino-3-methylimidazo[4,5-f]quinoline in Livers of Rats Using Capillary Liquid Chromatography/Microelectrospray Mass Spectrometry: A Dose-Response Study. Anal. Chem. 2001, 73, 2819.

22. Paehler, A.; Richoz, J.; Soglia, J.; Vourous, P.; Turesky, R. J. Analysis and Quantification of DNA Adducts of 2-Amino-3,8-dimethylimidazo[4,5f]quinoxaline in Liver of Rats by Liquid Chromatography/Electrospray Tandem Mass Spectrometry. Chem. Res. Toxicol. 2002, 15 551-561.

23. Doerge, D. R.; da Costa, G. G.; McDaniel, L. P.; Churchwell, M. I. Twaddle, N. C.; Beland, F. A. DNA Damage and DNA Adduct Formation in Rat Tissues Following Oral Administration of Acrylamide. Mutat. Res. 2005, 580, 131-141.

24. Maniere, I.; Godard, T.; Doerge, D. R.; Churchwell, M. I.; Guffroy, M.; Laurentie, M.; Poul, J. M. DNA Damage and DNA Adduct Formation in Rat Tissues Following Oral Administration of Acrylamide. Mutat. Res. 2005, 580, 119-129.

25. Randerath, K.; Randerath, E.; Agrawal, H. P.; Gupta, R. C.; Schurdak, M. E.; Reddy, M. V. Postlabeling Methods for Carcinogen-DNA Adduct Analysis. Environ. Health Perspect. 1985, 63, 57-65.

26. Harris, T. M.; Stone, M. P.; Harris, C. M. Applications of NMR Spectroscopy to Studies of Reactive Intermediates and Their Interactions with Nucleic Acids. Chem. Res. Toxicol. 1988, 1, 79-96.

27. Sayer, J. M.; Chadha, A.; Agarwal, S. K.; Yeh, H. J.; Yagi, H.; Jerina, D. M. Covalent Nucleoside Adducts of Benzo[A]pyrene 7,8-Diol 9,10eposide-Structural Reinvestigation and Characterization of a Nove Adenosine Adduct on the Ribose Moiety. J. Org. Chem. 1991, 56, 20-29.

28. Schmeiser, H. H.; Pool, B. L.; Wiessler, M. Identification and Mutagenicity of Metabolites of Aristolochic Acid Formed by Rat Liver. Carcinogenesis 1986, 7, 59-63.

29. Chan, W.; Cui, L.; Xu, G. W.; Cai, Z. W. Study of the Phase I and Phase II Metabolism of Nephrotoxin Aristolochic Acid by Liquid Chromatography Tandem Mass Spectrometry. Rapid Commun. Mass Spectrom. 2006, 20, 1755-1760.

30. Chaudhary, A. K.; Nokubo, M.; Oglesby, T. D.; Marnett, L. J.; Blair, I. A. Characterization of Endogenous DNA-Adducts by Liquidchromatography Electrospray-Ionization Tandem Mass Spectrometry. J. Mass Spectrom. 1995, 30, 1157-1166.

31. Qiu, S. X.; Yang, R. Z.; Gross, M. L. Synthesis and Liquid Chromatography/ Tandem Mass Spectrometric Characterization of the Adducts of Bisphenol A $o$-Quinone with Glutathione and Nucleotide Monophosphates. Chem. Res. Toxicol. 2004, 17, 1038-1046.

32. Singh, G.; Gutierrez, A.; Xu, K. Y.; Blair, I. A. Liquid Chromatography/ Electron Capture Atmospheric Pressure Chemical ionization/Mass Spectrometry: Analysis of Pentafluorobenzyl Derivatives of Biomolecules and Drugs in the Attomole Range. Anal. Chem. 2000, 72, 3007-3013.

33. Akasu, M.; Hokwa, H.; Fujita, M. Four New Fluorescent Compounds Isolated from the Callus Tissue of Stephanica cepharantha. Tetrahedron Lett. 1974, 41, 3609

34. Krumbiegel, G.; Hallensleben, J.; Mennicke, W. H.; Rittmann, N. Studies on the Metabolism of Aristolochic Acids I and II. Xenobiotica 1987, 17 981.

35. Broschard, T. H.; Wiessler, M.; Schmeiser, H. H. Effect of Site-specifically Located Aristolochic Acid DNA Adducts on In Vitro DNA Synthesis by Human DNA Polymerase Alpha. Cancer Lett. 1995, 98, 47-56.

36. Arlt, V. M.; Wiessler, M.; Schmeiser, H. H. Using Polymerase Arrest to Detect DNA Binding Specificity of Aristolochic Acid in the Mouse H-ras Gene. Carcinogenesis 2000, 21, 235-242.

37. Arlt, V. M.; Schmeiser, H. H.; Pfiefer, G. P. Sequence-specific Detection of Aristolochic Acid-DNA Adducts in the Human p53 Gene by Terminal Transferase-dependent PCR. Carcinogenesis 2001, 22, 133-140.

38. Debrauwer, L.; Rathahao, E.; Jouanin, I.; Paris, A.; Clodic, G.; Molines, H.; Convert, O.; Fournier F.; Tabet, J. C. Investigation of the Regio- and Stereo-selectivity of Deoxyguanosine Linkage to Deuterated 2Hydroxyestradiol by Using Liquid Chromatography/ESI-Ion Trap Mass Spectrometry. J. Am. Soc. Mass Spectrom. 2003, 14, 364-372. 